\title{
Variation in the Sizes of Chthamalid Barnacle Post-Settlement Cyprids on European Shores
}

\author{
Ruth M. O'Riordan ${ }^{1}$, Jane Delany ${ }^{1,2}$, David McGrath ${ }^{1,3}$, Alan A. Myers ${ }^{1}$, \\ Anne Marie Power ${ }^{1,4}$, Neil F. Ramsay ${ }^{1}$, Damaso Alvarez ${ }^{5}$, Teresa Cruz ${ }^{6}$, \\ Federica G. Pannacciulli ${ }^{7,8}$, Pedro Range ${ }^{9} \&$ Giulio Relini $^{7}$ \\ ${ }^{1}$ Department of Zoology and Animal Ecology, University College Cork, National University of \\ Ireland-Cork, Lee Maltings, Prospect Row, Cork City, Ireland. \\ ${ }^{2}$ Present address: Dove Marine Laboratory, University of Newcastle, Cullercoats, North Shields, \\ Tyne and Wear NE30 4PZ, England. \\ ${ }^{3}$ Department of Life Sciences, Galway-Mayo Institute of Technology, Galway, Ireland. \\ ${ }^{4}$ Present address: Cavanilles Institute of Biodiversity \& Evolutionary Biology, University of \\ València, Polìgono de la Coma s/n, 46980 Paterna, València, Spain. \\ ${ }^{5}$ Unidad de Ecologia, Departmento de Biologia de Organismos y Sistemas, Universidad da \\ Oviedo, 33071-Oviedo, Spain. \\ ${ }^{6}$ Laboratório de Ciências do Mar, Universidade de Évora, Apartado 190, 7521 Sines Codex, \\ Portugal. \\ ${ }^{7}$ Laboratori di Biologia Marina ed Ecologia Animale, DIP.TE.RIS, Università di Genova, Via \\ Balbi 5, Genova 16126, Italy. \\ ${ }^{8}$ Present address: Marine Environment Research Centre, ENEA - Santa Teresa, P.O. Box 224, \\ Pozzuolo di Lerici, 19100-La Spezia, Italy. \\ ${ }^{9}$ Laboratório Marítimo da Guia, Estrada do Guincho, 2750 Cascais, Portugal.
}

With 2 figures and 6 tables

Keywords: Chthamalid barnacles, cyprids, settlement, Europe.

\begin{abstract}
As part of a wider study on the settlement and recruitment of Chthamalus spp. in Europe, this study investigated whether chthamalid cyprids can be separated by length on a European scale. Variation in cyprid length with latitude and temporal variation at selected localities were also examined. The lengths of cyprids collected between 1996-1999 on nine rocky shores in Europe are reported. Elminius modestus cyprids were found only at Roscoff, NW France and could be distinguished due to their carapace shape and length. They showed a unimodal length distribution, measuring between 450 and $625 \mu \mathrm{m}$, with no variation in length between the two sampling dates (1997 and 1998). Based on carapace shape and length, the remaining cyprids in the collections were identified as one of three chthamalid species, Chthamalus montagui, Chthamalus stellatus or Euraphia depressa. Bimodal length distributions of chthamalid cyprids were seen on some shores, while others had a single small-sized modal group (representing C. montagui on Atlantic shores and/or E. depressa in the Mediterranean)
\end{abstract}

\footnotetext{
* Author to whom correspondence should be addressed. E-mail: r.oriordan@ucc.ie
} 